\title{
Relationship of Race and Proteinuria to Renal Function Decline in Patients with CKD
}

Steven Rosansky ${ }^{1 *}$, Martin Durkin ${ }^{2}$, James Hardin ${ }^{3}$, Kirby Jackson ${ }^{3}$, Csaba Kovesdy ${ }^{4}$, Jessica Sontrop ${ }^{5}$, Justin Reynolds ${ }^{1}$, Kathlyn Haddock ${ }^{1}$, Frankie Richards ${ }^{1}$ and William Clark $^{5}$

${ }^{1}$ WJBDVA Hospital, Dorn Research Institute, University of South Carolina School of Public Health, Columbia, SC, USA

${ }^{2}$ Palmetto Health Hospital, Research Service, Columbia, SC, USA

${ }^{3}$ University of South Carolina School of Public Health, Columbia, SC, USA

${ }^{4}$ Memphis VA Medical Center, Nephrology, Memphis, TN, India

${ }^{5}$ Division of Nephrology London Health Sciences Centre London, Ontario, UK

*Corresponding author: Steven Rosansky, WJBD VA Hospital, Dorn Research Institute, University of South Carolina School of Public Health, Columbia, SC, USA, 526 N Trenholm Rd, Columbia SC 29206, USA, Tel: 8034225427; E-mail: sjrcra@yahoo.com

Rec date: Mar 31, 2014, Acc date: May 10, 2014, Pub date: May 17, 2014

Copyright: (c) 2014 Rosansky S, et al. This is an open-access article distributed under the terms of the Creative Commons Attribution License, which permits unrestricted use, distribution, and reproduction in any medium, provided the original author and source are credited.

\begin{abstract}
Background: To date, the reasons for the higher rates of treated end-stage renal failure in blacks versus whites are poorly understood. Proteinuria is the most important determinant of renal function loss (RFL). Blacks have a higher incidence of proteinuric CKD than whites. The current study evaluates the hypothesis that after adjustment for proteinuria, blacks have faster RFL, more prominent at lower levels of estimated glomerular filtration rates (eGFR).

Methods: In a non-referral outpatient CKD population of 1,935 blacks and 6,286 whites, the relationship of zero, $<2$ plus and $\geq 2$ plus dipstick proteinuria to MDRD e GFR change per year (RFL) was analyzed. Next the relationship between race and RFL was examined in patients with higher versus lower eGFR (defined by never or ever having an eGFR $<30 \mathrm{ml} / \mathrm{min} / 1.73 \mathrm{~m}^{2}$, respectively during the study using a mixed effects model which includes longitudinal urinalysis (log converted), serum creatinine data points, age and whether a patient died during the study. Results: Versus whites, blacks had higher baseline e GFR $\left(75.3 \mathrm{ml} / \mathrm{min} / 1.73 \mathrm{~m}^{2}\right.$ versus $\left.64.9 \mathrm{ml} / \mathrm{min} / 1.73 \mathrm{~m}^{2}\right)$ higher frequency of e GFR $<30 \mathrm{ml} / \mathrm{min} / 1.73 \mathrm{~m}^{2}(30.8 \%$ versus $21 \%)$, higher dipstick proteinuria levels and faster $\mathrm{RFL}$ by proteinuria group (range -1.07 to $-2.28 \mathrm{ml} / \mathrm{min} / \mathrm{m}^{2} /$ year in blacks and -0.68 to $-1.80 \mathrm{ml} / \mathrm{min} / 1.73 \mathrm{~m}^{2} /$ year, in whites), $p<0.01$. In the mixed effects model, blacks had a 0.30 and $0.59 \mathrm{ml} / \mathrm{min} / 1.73 \mathrm{~m}^{2} /$ year, faster loss of renal function in the higher and lower eGFR groups, respectively, $p<0.001$.
\end{abstract}

Conclusion: Blacks with CKD appear to lose renal function faster than whites. This effect may be more pronounced at lower e GFR levels.

\section{Keywords:}

\section{Introduction}

American blacks are four times more likely to initiate dialysis than American whites [1]. One possible explanation for this is a higher rate of progression to advanced chronic kidney disease (CKD) in blacks. Proteinuria has been reported to be the single strongest predictor of renal disease progression at all levels renal function [2]. Few studies to date have examined comparative rates of renal function loss (RFL) in blacks versus whites [1]. Most published studies included: patients with (eGFR) $>60 \mathrm{ml} / \mathrm{min} / 1.73 \mathrm{~m}^{2}$; few longitudinal data points; short follow-up ( $<3$ years), and few include the effect of albuminuria on RFL. Recently, Ericksen, et al. reported that in the in a non-referral Veterans Administration (VA) outpatient population of 1,935 blacks and 6,286 whites with an eGFR $\leq 60 \mathrm{ml} / \mathrm{min} / 1.73 \mathrm{~m}^{2}$, followed for an average of nine years with higher or lower eGFR levels defined by never or ever having an eGFR $<30 \mathrm{ml} / \mathrm{min} / 1.73 \mathrm{~m}^{2}$ during the study interval, respectively.

\section{Concise Methods}

Patients from the Dorn VA Hospital, Columbia, SC who ever had a serum creatinine of $1.3 \mathrm{mg} / \mathrm{dl}$ (chosen to find patients with eGFR $<60$ $\mathrm{ml} / \mathrm{min} / 1.73 \mathrm{~m}^{2}$ ) or greater during the interval 1989-2003 were included in the analysis. Patients were followed until December 31, 2008. eGFR was calculated utilizing the four variable equations from the modification of diet in renal disease (MDRD) study. The same automated serum creatinine methodology is used throughout the study (Beckman Coulter Synchron System Jaffe rate method). Only outpatient serum creatinine values were used to avoid the confounding effect of illness on eGFR (i.e., acute kidney injury). In order to enter the study a patient required a minimum of: three-serum creatinine values over a minimum of three years of follow-up; at least one urinalysis with dipstick proteinuria measurement, and information on age and race. Subject specific measurements: whether died while under observation, whether the patient ever had an eGFR < $30 \mathrm{ml} / \mathrm{min} / 1.73 \mathrm{~m}^{2}$, the total number of and date of each serum creatinine measure, the total number and date of each urinalysis protein measure, and race were collected. Proteinuria was classified into three groups utilizing all urinalysis data, evaluated by automated colorimetric dipstick analysis, to define the following proteinuria 
Page 2 of 4

groupings: group 1, no proteinuria on any dipstick tests, group 2 $<2$ plus proteinuria $(100 \mathrm{mg} / \mathrm{dl})$ on all tests, group $3, \geq 2$ plus $(100$ $\mathrm{mg} / \mathrm{dl}$ ) on at least one urinalysis. The date of each urinalysis and creatinine measure was recorded. The relationship of RFL to level of urinalysis proteinuria was compared by race and by proteinuria group. Statistical significance by $t$ test, and medians and interquartile ranges are reported. Proteinuria was included in the regression analysis by taking urine protein measures closest to longitudinal serum creatinine values. Given the units in which protein was recorded, dipstick proteinuria values of $10 \mathrm{mg} / \mathrm{dl}$ (trace), 1 plus proteinuria $(30 \mathrm{mg} / \mathrm{dl}), 2$ plus proteinuria $(100 \mathrm{mg} / \mathrm{dl}), 3$ plus proteinuria $(300 \mathrm{mg} / \mathrm{dl})$ and 4 plus proteinuria, $1000 \mathrm{mg} / \mathrm{dl}$ ), were $\log 10$ transformed. We added 1 to the proteinuria measure to avoid numeric problems with measurement results of zero. Chi squared analysis for categorical and t test for continuous variables was used to test for statistical significance. We estimated the rate of change in eGFR $\left(\mathrm{ml} / \mathrm{min} / 1.73 \mathrm{~m}^{2}\right.$ per year) using a mixed-effects linear regression model (Stata), which allows for multiple observations per patient. Predictor variables for regression model includes, whether died while under observation, whether the patient ever had an eGFR $<30 \mathrm{ml} / \mathrm{min} / 1.73 \mathrm{~m}^{2}$, all dated serum creatinine measures, all log converted urine protein values matching the urine protein closest to a dated serum creatinine value, and race for each person. Time is measured in years and interactions with time in years were examined by race, and ever had eGFR $<30 \mathrm{ml} / \mathrm{min} / 1.73$ $\mathrm{m}^{2}$. Patients who ever had an eGFR of $<15 \mathrm{ml} / \mathrm{min} / 1.73 \mathrm{~m}^{2}$ were compared in blacks and whites.

\section{Main Results}

Table 1 summarizes the subject characteristics and outcomes (medians and interquartile range) for the 8,221 subjects, $23.5 \%$ of who were black. The following parameters were significantly different in blacks versus whites at the $\mathrm{p}<.001$ level, age 61.2 in blacks, 65.1 in whites, follow-up 9.9 years in blacks, 8.9 years in whites, mean serum creatinine measures/urine protein measures $25 / 8$ in blacks, $19 / 6$ in whites, median eGFR during the first 12 months $75.3 \mathrm{ml} / \mathrm{min} / 1.73 \mathrm{~m}^{2}$ in blacks vs. $64.9 \mathrm{ml} / \mathrm{min} / 1.73 \mathrm{~m}^{2}$ in whites, patients who ever had an eGFR $<30 \mathrm{ml} / \mathrm{min} / 1.73 \mathrm{~m}^{2}$ and an eGFR $<15 \mathrm{ml} / \mathrm{min} / 1.73 \mathrm{~m}^{2}$, in blacks versus whites was $30.8 \%$ versus $21 \%$, and $13.6 \%$ versus $6.3 \%$, respectively. There was no significant difference in number of black versus white patients who died during the study. Table 1 also presents the change in eGFR $\left(\mathrm{ml} / \mathrm{min} / 1.73 \mathrm{~m}^{2}\right.$ per year), utilizing the difference between the average of the first and average of the last years eGFR divided by time in years for three urine protein groups. Blacks had a higher frequency of urine protein group 2 compared with whites (Table 1). For blacks and whites, loss of eGFR was more rapid in those with higher levels of proteinuria. Median eGFR slope in $\mathrm{ml} / \mathrm{min} / 1.73$ $\mathrm{m}^{2}$ /year ranged from -0.74 for those with no proteinuria to -1.96 for those with at least one urinalysis with $\geq 2+$ proteinuria, $\mathrm{p}<0.01$. Unadjusted eGFR slope $\left(\mathrm{ml} / \mathrm{min} / 1.73 \mathrm{~m}^{2} /\right.$ year $)$ was significantly higher in blacks versus whites overall, -1.94 vs. -1.24 and after stratification by levels of proteinuria; group $0,-1.62$ vs. -0.96 ; group $1,-1.07$ vs. -0.68 ; group $2,-2.28$ vs. $-1.8, \mathrm{p}<.01$.

\begin{tabular}{|c|c|c|c|}
\hline & All & Black $^{2}$ & White \\
\hline Population (N) & 8221 & 1935 & 6286 \\
\hline Age & $64.4(54.8-71.0)^{1}$ & $61.2(49.4-68.9)$ & $65.1(56.6-71.5)$ \\
\hline Follow-up time in years & $9.09(6.43-13.12)$ & $9.85(6.8-14.3)$ & $8.9(6.3-12.7)$ \\
\hline \# of Creatinine Measures & $20(12-31)$ & $25(15-40)$ & $19(12-29)$ \\
\hline \# of Protein Measures & $6(3-12)$ & $8(4-14)$ & $6(3-11)$ \\
\hline Average of first 12 mos. eGFR ${ }^{3}$ & $66.9(57.3-77.8)$ & $75.3(62.3-88.7)$ & $64.9(56.6-74.5)$ \\
\hline Average of last 12 mos. eGFR ${ }^{3}$ & $56.6(43.8-67.6)$ & $59.1(42.2-72.7)$ & $56.0(44.1-66.3)$ \\
\hline Protein Group $0^{4}$ & $37.30 \%$ & $22.40 \%$ & $41.90 \%$ \\
\hline Protein Group $1^{5}$ & $32.70 \%$ & $31.20 \%$ & $33.20 \%$ \\
\hline Protein Group $2^{6}$ & $32.20 \%$ & $46.40 \%$ & $24.90 \%$ \\
\hline $\mathrm{RFL}^{7}$ Group $0^{8}$ & $-0.74(-1.7,0.27)$ & $-1.07(-2.5,0.17)$ & $-0.68(-1.8,0.28)$ \\
\hline RFL Group $1^{8}$ & $-0.95(-2.10,0.06)$ & $-1.13(-2.5,0.7)$ & $-0.91(2.0,0.50)$ \\
\hline RFL Group $2^{8}$ & $-1.96(-3.8,-0.46)$ & $-2.28(-4.1,-0.75)$ & $-1.8(-3.6,-0.35)$ \\
\hline Died during study & $33.30 \%$ & $35.30 \%$ & $32.70 \%$ \\
\hline Ever eGFR $<30 \mathrm{ml} / \mathrm{min} / 1.73 \mathrm{~m}^{2}, 9$ & $23.20 \%$ & $30.80 \%$ & $21.00 \%$ \\
\hline Ever eGFR $<15 \mathrm{ml} / \mathrm{min} / 1.73 \mathrm{~m}^{2}, 10$ & $8.00 \%$ & $13.60 \%$ & $6.30 \%$ \\
\hline
\end{tabular}

Table 1: Subject Characteristics ${ }^{1}$

1. Median (interquartile range)

2. Black versus white characteristics for all $=\mathrm{P}<.001$, except died during study $=\mathrm{P}<.04$
3. Estimated GRF (eGFR) using 4 variable MDRD equation in $\mathrm{ml} / \mathrm{min} / 1.73 \mathrm{~m}^{2}$

4. Protein Group 0: all urinalysis protein results negative 
5. Protein Group 1: urinalysis results trace to $1+$ protein $(30 \mathrm{mg} / \mathrm{dL})$

6. Protein Group 2: urinalysis results had at least one urinalysis result $\geq 2$ plus protein $(100 \mathrm{mg} / \mathrm{dL})$

7. Renal function loss (RFL) change in eGFR per year

8. Median (interquartile range) for RFL in $\mathrm{ml} / \mathrm{min} / 1.73 \mathrm{~m}^{2} /$ years, calculated as the difference in the average eGFR of the last 12 months minus the average of the first 12 months, divided by the years of follow up.

\section{Had an eGFR $<30 \mathrm{ml} / \mathrm{min} / 1.73 \mathrm{~m}^{2}$ at some point of the study}

10. Had an eGFR $<15 \mathrm{ml} / \mathrm{min} / 1.73 \mathrm{~m}^{2}$ at some point in the study

The random effects model (Table 2) examines the difference between blacks and whites in the change in eGFR per year. Interaction terms not included in Table 2 were all not statistically significant (blacks died, blacks died years, blacks ever 30 )

Compared to a white patient for each log protein unit increase in urine proteinuria, blacks had a $-1.0 \mathrm{ml} / \mathrm{min} / 1.73 \mathrm{~m}^{2}$ lower eGFR data point. The other coefficients in the model all reported as $\mathrm{ml} / \mathrm{min} / 1.73$ $\mathrm{m}^{2} /$ year were, years- 0.17 , black years -0.30 , ever 30 years -1.58 , black ever 30 years, -0.29 . For those whites who never had an eGFR $<30$, the RFL was -0.17 for whites; $-0.17+-0.30=-0.47$ for blacks. For those who ever had an eGFR < 30 for whites RFL was $-0.17+-1.58=-1.75$; RFL for blacks was $-0.17+-0.30+-1.58+-0.29=-2.35 \mathrm{ml} / \mathrm{min} / 1.73 \mathrm{~m}^{2} /$ year. Thus the RFL difference between blacks and whites was $-0.30 \mathrm{ml} / \mathrm{min} / 1.73$ $\mathrm{m}^{2} /$ year if never had eGFR $<30$ and $-0.60 \mathrm{ml} / \mathrm{min} / 1.73 \mathrm{~m}^{2}$ if ever had eGFR $<30$.

\begin{tabular}{|l|l|l|l|l|}
\hline & Black & White & Difference & P Value \\
\hline Constant & 104.10 & 92.80 & 11.40 & $<.001$ \\
\hline eGFR 30 & -7.57 & -7.80 & 0.23 & NS \\
\hline Died & (1.43 & 2.80 & -0.75 & NS \\
\hline Log protein & -3.00 & -2.00 & -1.00 & $<.001$ \\
\hline Age $^{6}$ & -0.49 & -0.49 & 0 & NS \\
\hline Male & 5.90 & 5.90 & 0 & NS \\
\hline No eGFR 30 rss $^{7}$ & -0.47 & -0.17 & -0.30 & $<.001$ \\
\hline Yes eGFR 30 .rs $^{8}$ & -2.35 & -1.75 & -0.29 & $<.001$ \\
\hline
\end{tabular}

Table 2: Mixed Effects Model of Black versus White RFL Differences ${ }^{1,2}$

1. RFL-Renal function loss, rate of decline of MDRD eGFR in $\mathrm{ml} / \mathrm{min} / 1.73 \mathrm{~m}^{2} /$ year

\section{Reported coefficient and $p$ values of mixed effects model}

3. eGFR 30 defined as subpopulation who ever had eGFR $<30$ $\mathrm{ml} / \mathrm{min} / 1.73 \mathrm{~m}^{2}$ during study

\section{Died during study}

5. Log to base 10 converted urinalysis where trace $=10,1+=30,2+$ $=100,3+=300,4+=1000$.

\section{Age at entry}

7. Interaction term of change in eGFR/year for patients who did not have eGFR $<30 \mathrm{ml} / \mathrm{min} / 1.73 \mathrm{~m}^{2}$ during the study. Values of coefficients are in $\mathrm{ml} / \mathrm{min} / 1.73 \mathrm{~m}^{2} / \mathrm{yr}$. The coefficient for whites $=-0.17$, for blacks $=-0.30+-0.47$.

8. Interaction term of patients who ever had an eGFR $<30$ during the study. Values of coefficients are in $\mathrm{ml} / \mathrm{min} / 1.73 \mathrm{~m}^{2} / \mathrm{yr}$. The coefficient for whites who ever had eGFR $<30 \mathrm{ml} / \mathrm{min} / 1.73 \mathrm{~m}^{2}$ is $-1.58+-0.17=-1.75$, for blacks who ever had eGFR $<30 \mathrm{ml} / \mathrm{min} / 1.73 \mathrm{~m}^{2}$ is $-1.75+-0.47$ (black ever 30 years+years coefficients) $=-2.35$

\section{Implications/discussion}

This is the first report in a non-referral black and white CKD population, followed for an average of nine years that compares rates of eGFR decline among blacks and whites after adjustment for level of proteinuria. Few studies have compared rates of eGFR decline in blacks versus whites [1]. Most included patients with an eGFR $>60$ $\mathrm{ml} / \mathrm{min} / 1.73 \mathrm{~m}^{2}$, and had only limited follow-up ( $<3$ years) and few included the effect of albuminuria on decline in eGFR. Recently the need for long-term follow-up to adequately assess RFL has been emphasized [4]. Using reciprocal of serum creatinine as a measure of renal function, Brazy and Fitzwilliams found no difference in renal function loss in 112 blacks and 88 white VA patients followed an average of nine years [5]. However, these results did not account for differences in proteinuria. In a relatively small ( 289 blacks, 945 whites) proteinuric (approximately $800 \mathrm{mg} / 24$ hour) referral VA renal clinic population, with advanced CKD (mean initial eGFR $37 \mathrm{ml} / \mathrm{min} / 1.73$ $\mathrm{m}^{2}$ ) followed for 2.8 years, Kovesdy, et al. found no difference in blacks versus white RFL after adjustment for proteinuria and other comorbidities [6].

In the current study, the higher frequency of 2+proteinuria (100 $\mathrm{mg} / \mathrm{dl}$ ) in blacks versus whites $(46.4 \%$ versus $24.9 \%$, Table 1 ) may relate to the finding that although blacks started out with higher first year average eGFR, they were approximately 50\% more likely to develop CKD 4 and twice as likely to develop CKD 5 (Table 1).

Gansevoort, et al. used a modification of the method of calculating RFL in Table 1 on the Chronic Kidney Disease Prognosis Consortium data [7]. In that report, the difference between initial and final eGFR divided by years of follow-up was used to calculate RFL and log

roteinuria appears to influence the rate of change of eGFR per year more so in blacks than whites (Table 1). The mixed effects model (Table 2) utilizing all serum creatinine and urinalysis data points confirms this finding. Compared to whites, blacks had a $-0.30 \mathrm{ml} / \mathrm{min} /$ $1.73 \mathrm{~m}^{2} /$ year greater decline in eGFR in the higher renal function group (never had an eGFR $<30 \mathrm{ml} / \mathrm{min} / 1.73 \mathrm{~m}^{2}$ ) and a $-0.60 \mathrm{ml} / \mathrm{min} /$ $1.73 \mathrm{~m}^{2}$ /year greater difference in the lower eGFR subset (had at least one e GFR $<30 \mathrm{ml} / \mathrm{min} / 1.73 \mathrm{~m}^{2}$ ). The failure of the two prior VA based studies to find a RFL difference in blacks versus whites may relate to their shorter follow-up, higher baseline serum creatinine (lower initial eGFR) or the lack of comorbidity adjustment in the current study $[3,4]$.

The higher baseline e GFR in blacks versus whites in the current study may partly relate to the method of choosing patients for entry in to the study. To enroll in the study, patients need at least one serum creatinine of $1.3 \mathrm{mg} / \mathrm{dL}$ or greater. A serum creatinine of $1.3 \mathrm{mg} / \mathrm{dl}$ would translate in to a higher e GFR by the MDRD equation in blacks versus whites as a result of the MDRD formulae. It is possible that in the current study, blacks had a slower rate of loss of renal function at $\mathrm{e}$ GFR levels over $60 \mathrm{ml} / \mathrm{min} / 1.73 \mathrm{~m}^{2}$ followed by a slower rate of loss at e GFR $<60 \mathrm{ml} / \mathrm{min} / 1.73 \mathrm{~m}^{2}$. A recent study by Peralta et al. found the 
reverse, that blacks had a faster RFL than whites at e GFR levels above $60 \mathrm{ml} / \mathrm{min} / 1.73 \mathrm{~m}^{2}$ [8].

Proteinuria is the most important factor that affects RFL. In a large Norwegian cohort followed 10.3 years, Hallan, et al. found that after adjusting for proteinuria and eGFR, none of the other variables examined including hypertension, diabetes, obesity, cardiovascular disease, smoking, and education predicted development of treated ESRD [9]. Similarly, Muntner, et al. found that after adjusting for eGFR and albuminuria other comorbidity and life style risk factors did not predict development of ESRD in blacks [10]. On the other hand, McClellan, et al. found that albuminuria prevalence and severity explained some of the excess risk of ESRD in blacks versus whites, but this relationship was attenuated by social and comorbidity factor adjustments [11]. VA care helps minimize some of the socioeconomic issues in black versus white medical care since it is assumed that both races have equal access to care in the VA system.

With regards to survival, similar fractions of blacks and whites in the current study died, $35.3 \%$ and $32.7 \%$ respectively and death during the study did not appear to be a significant factor in the mixed effects model (Table 2). The majority of the reported data on relative risk of death in blacks versus whites with similar levels of renal function found no difference or a higher death rate in blacks versus whites [12-14]. Thus, although we do not provide a formal survival analysis, a faster RFL in whites who died (censoring of data) is probably not the explanation for the black /white RFL difference.

The pathophysiology behind the putative faster loss of renal function in blacks versus whites may relate to the "genetic hypothesis" [15], which associate the faster decline in blacks to the presence of the APOL 1 gene. In a recent report by Parsa et al. using data from the African American Study of Kidney Disease and Hypertension (AASK) and from the Chronic Renal Insufficiency Cohort (CRIC) study, patients with two copies of this gene were twice as likely to reach a renal end point as those with no or one copy of the gene [15]. This faster rate of loss did not appear to be related to degree of blood pressure control or presence of diabetes. Other studies found that the association of APOL1 genotype and faster RFL was not present in diabetics. Socioeconomic factors and other pathophysiological factors may also relate to the difference in black white RFL [11].

Others have reported dipstick proteinuria as a predictor of RFL with a similar finding of faster RFL with higher levels of dipstick proteinuria $[16,17]$. The utility of the urinalysis protein groups in the current study and the best predictor variable (initial value, all values, change in proteinuria) for log converted urinalysis proteinuria versus RFL needs further exploration. The faster RFL in blacks versus whites that appears to be increased at lower eGFR levels in the current study (Table 2) needs to be replicated in studies that control for social and comorbidity variables (including diagnosis diabetes), survival, as well as episodes of acute kidney injury and renal decline patterns [18].

\section{References}

1. Barbour SJ, Schachter M, Er L, Djurdjev O, Levin A (2010) A systematic review of ethnic differences in the rate of renal progression in CKD patients. Nephrol Dial Transplant 25: 2422-2430.
2. Levey AS, de Jong PE, Coresh J, El Nahas M, Astor BC, et al. (2011) The definition, classification, and prognosis of chronic kidney disease: a KDIGO Controversies Conference report. Kidney Int 80: 17-28.

3. Eriksen BO, Ingebretsen OC (2007) In chronic kidney disease staging the use of the chronicity criterion affects prognosis and the rate of progression. Kidney Int 72: 1242-1248.

4. Levin A, Djurdjev O (2012) On being better kidney doctors: understanding trajectories, probabilities, predictability, and people. Am J Kidney Dis 59: 475-477.

5. Brazy PC, Fitzwilliam JF (1990) Progressive renal disease: role of race and antihypertensive medications. Kidney Int 37: 1113-1119.

6. Kovesdy CP, Anderson JE, Derose SF, Kalantar-Zadeh K (2009) Outcomes associated with race in males with nondialysis-dependent chronic kidney disease. Clin J Am Soc Nephrol 4: 973-978.

7. Gansevoort RT, Matsushita K, van der Velde M, Astor BC, Woodward $\mathrm{M}$, et al. (2011) Lower estimated GFR and higher albuminuria are associated with adverse kidney outcomes. A collaborative meta-analysis of general?and high-risk population cohorts. Kidney International 80: 93-104.

8. Peralta CA, Katz R, DeBoer I, Ix J, Sarnak M, et al. (2011) Racial and ethnic differences in kidney function decline among persons without chronic kidney disease. J Am Soc Nephrol 22: 1327-1334.

9. Hallan SI, Ritz E, Lydersen S, Romundstad S, Kvenild K, et al. (2009) Combining GFR and albuminuria to classify CKD improves prediction of ESRD. J Am Soc Nephrol 20: 1069-1077.

10. Muntner P, Judd SE, Gao L, Gutiérrez OM, Rizk DV, et al. (2013) Cardiovascular risk factors in CKD associate with both ESRD and mortality. J Am Soc Nephrol 24: 1159-1165.

11. McClellan WM, Warnock DG, Judd S, Muntner P, Kewalramani R, et al. (2011) Albuminuria and racial disparities in the risk for ESRD. J Am Soc Nephrol 22: 1721-1728.

12. Choi AI, Rodriguez RA, Bacchetti P, Bertenthal D, Hernandez GT, et al. (2009) White/black racial differences in risk of end-stage renal disease and death. Am J Med 122: 672-678.

13. Xue JL, Eggers PW, Agodoa LY, Foley RN, Collins AJ (2007) Longitudinal study of racial and ethnic differences in developing endstage renal disease among aged medicare beneficiaries. J Am Soc Nephrol 18: $1299-1306$

14. Derose SF, Rutkowski MP, Levin NW, Liu IL, Shi JM, et al. (2009) Incidence of end-stage renal disease and death among insured African Americans with chronic kidney disease. Kidney Int 76: 629-637.

15. Williams WW, Pollak MR (2013) Health disparities in kidney disease-emerging data from the human genome. N Engl J Med 369: 2260-2261.

16. Ishani A, Grandits GA, Grimm RH, Svendsen KH, Collins AJ, et al. (2006) Association of single measurements of dipstick proteinuria, estimated glomerular filtration rate, and hematocrit with 25- year incidence of end-stage renal disease in the multiple risk factor intervention trial. J Am Soc Nephrol 17: 1444-1452.

17. Clark WF, Macnab JJ, Sontrop JM, Jain AK, Moist L, et al. (2011) Dipstick proteinuria as a screening strategy to identify rapid renal decline. J Am Soc Nephrol 22: 1729-1736.

18. Li L, Astor BC, Lewis J, Hu B, Appel LJ, et al. (2012) Longitudinal progression trajectory of GFR among patients with CKD. Am J Kidney Dis 59: 504-512. 